\title{
Методика оцінювання здатності національної економіки забезпечити достатній рівень воєнної безпеки держави
}

\author{
Олег Семененко * А; Ігор Москаленко ${ }^{\text {; }}$ Сергій Середюк ${ }^{\text {; }}$ \\ Ольга Романченко ${ }^{B}$; Іван Мотрунич ${ }^{\text {; }}$ Вікторія Коверга ${ }^{A}$ \\ А Центральний науково-дослідний інститут Збройних Сил України, пр-кт Повітрофлотський 28, м. Київ, 03049, Україна \\ в Національний університет оборони України імені Івана Черняховського, пр-кт Повітрофлотський 28, м. Київ, 03049, Україна \\ с Центр забезпечення службової діяльності Міністерства оборони та Генерального штабу збройних Сил України, \\ пр-кт Повітрофлотський 6, м. Київ, 03168, Україна
}

Received: December 04, 2020 | Revised: December 13, 2020 | Accepted: December 31, 2020

JEL Classification: D04, E17

DOI: $10.33445 /$ sds.2020.10.6.9

\begin{abstract}
Анотація
Сьогодні $€$ багато суперечливих поглядів на можливості оцінювання взаємозв'язку показників рівня воєнної безпеки держави та показників його ресурсної забезпеченості, які характеризують стан розвитку національної економіки держави, але чіткого послідовного підходу до вирішення такого завдання до теперішнього часу не має. Тому запропонована авторами у статті методика являє собою послідовність дій, яка повинна дозволяти проводити оцінювання рівня воєнної безпеки держави на визначений плановий час або період їі формування на основі оцінок стану або рівня забезпеченості різними видами ресурсів та їх складовими, які характеризують розвиток національної економіки держави. На основі результатів отриманих практичних розрахунків формуються практичні рекомендації та пропозиції, які будуть враховані на наступний плановий період формування показника необхідного рівня воєнної безпеки держави із урахуванням оцінок здатності національної економіки забезпечити цей рівень. Методика передбачається для використання спеціалістами оборонного планування стратегічного рівня під час проведення середньострокового та довгострокового оборонного планування, а також спеціалістами економічної сфери, які залучаються до вирішення завдань визначення та прогнозування рівня воєнної та економічної безпеки держави.

За результатами використання методики планується обґрунтовано визначати або уточнювати показники необхідного рівня розвитку національної економіки держави за напрямом ресурсного забезпечення воєнної безпеки держави на плановий момент (період) оцінювання під час середньострокового та довгострокового оборонного планування; проводити оцінку рівнів забезпеченості ресурсними можливостями національної економіки на визначений момент оцінювання та період планування; обгрунтовано, ефективно коригувати показники рівня воєнної безпеки держави та ресурсної забезпеченості за складовими національної економіки на визначений час (період); визначати чутливість отриманих оцінок до можливих змін вхідних даних та характеризувати стабільність прийнятих рішень на основі отриманих оцінок.
\end{abstract}

Ключові слова: воєнна безпека, економічна складова, національна економіка, ресурсні можливості, методика оцінювання, показники забезпечення, плановий період, види ресурсів, узагальнена схема.

\footnotetext{
* Corresponding author: д. військ. н., с.н.с., начальник відділу, e-mail: aosemenenko@ukr.net, ORCID: 0000-0001-6477-3414
} 


\section{Постановка проблеми}

Забезпечення достатнього рівня національної безпеки України в сучасній обстановці, що складається як в середині країни, так і навколо неї $\epsilon$ одним із пріоритетних завдань як керівництва країни, i кожного їі сумлінного громадянина. Одним із головних елементів достатнього рівня захищеності національних інтересів України зовні $\epsilon$ воєнна безпека держави, яка $\epsilon$ складовою національної безпеки та визначає стан захищеності національних інтересів, суверенітету, територіальної цілісності і недоторканності держави від посягань із застосуванням воєнної сили $[1-5,7]$. Сучасне визначення українського законодавства надає більш розширене трактування терміну: «воєнна безпека - захищеність державного суверенітету, територіальної цілісності і демократичного конституційного ладу та інших життєво важливих національних інтересів від воєнних загроз» $[1-4,7,15]$.

Воєнна безпека, як соціально-політичне явище, покликана протистояти воєнній небезпеці, тому в системі національної безпеки і оборони визначається також як оборона держави [1-8].

Головною метою забезпечення воєнної безпеки $€$ усунення зовнішніх і внутрішніх загроз національній безпеці держави у воєнній сфері та створення сприятливих умов для гарантованого захисту їі національних інтересів [1-6]. У міжнародній практиці воєнна безпека передбачає право суверенної держави на самооборону або стримування воєнної агресії, допускає можливість застосування державою воєнної сили для захисту власного суверенітету і територіальної цілісності [1-15].

Воєнна безпека України як одна з важливих складових національної безпеки, достатній рівень якої визначається складним комплексом політичних, економічних, військових та інших заходів. Переважне значення надається заходам політичного характеру, спрямованим на створення сприятливої для країни зовнішньої та внутрішньої обстановки, зміцнення міжнародного авторитету держави, усунення існуючих і потенційних конфліктних ситуацій. Однак ефективність цих заходів досягається лише за умов, якщо вони сполучаються з діями оборонного характеру, спрямованими на силове стримування можливого противника та блокування його спроб домогтися політичних цілей за допомогою зброї. Однією із найважливіших складових воєнної безпеки держави $\epsilon$ економічна складова [1-4], [8-12]. Забезпечення обороноздатності держави відбувається в умовах обмежень за ресурсними можливостями національної економіки держави: людськими, матеріальними та фінансовими. Прогнозовані ресурсні можливості національної економіки держави впливають на визначення граничних показників щодо економічної складової рівня воєнної безпеки держави під час планування оборони держави та відповідно і на рівень воєнної безпеки. Україна має нині значний потенціал щодо наявності людських, трудових, природних, матеріальних, енергетичних, технічних, інтелектуальних, наукових, виробничих ресурсів, які у разі їх правильного застосування можуть сприяти прискоренню економічного, соціального, воєнного розвитку держави шляхом створення конкурентоспроможної економіки [11, 13-15]. Національні інтереси України потребують негайного впровадження комплексу заходів щодо забезпечення ефективного використання наявних ресурсів 3 метою економічного прогресу, збільшення і зміцнення оборонного потенціалу (ОП) України, рівня ії̈ воєнноекономічної безпеки (ВЕБ) та відповідно рівня національної безпеки. Дослідження проблем оцінювання та збалансованого розвитку ВЕБ держави $€$ однією із головних складових проблематики подальшого розвитку України в цілому. Особливої актуальності це питання набуває в умовах бойового застосування частин та підрозділів ЗС України у виконанні завдань за призначенням, а також значних розбіжностей між потребами щодо розвитку воєнної складової держави та наявними для забезпечення цих потреб ресурсами, які реально виділяються для підтримки воєнного 
потенціалу (ВП) держави сьогодні. Дефіцит ресурсів національної економіки суттєво залежить від сформованих у суспільстві уявлень, у тому числі теоретичних, про роль і місце військової організації (ЗС України) у системі національної безпеки країни, про об'єктивні потреби і кінцеву результативність їі діяльності в реально сформованих геостратегічних, культурно-історичних і економіко-технологічних умовах $[3,9,10,12]$.

Вирішення проблеми дисбалансу між реальними ресурсними можливостями національної економіки держави та необхідним рівнем економічної складової воєнної безпеки $\epsilon$ сьогодні одним із пріоритетних завдань в процесах довгострокового та середньострокового оборонного планування. Аналіз результатів виконання Держаних програм розвитку ЗС України за попередні періоди показує існуючи проблеми, пов'язані із збалансованістю потреб ЗС України, як основного елемента забезпечення необхідного рівня воєнної безпеки, та станом забезпеченості цих потреб показниками ресурсних можливостей держави (мал. 1). Цьому питанню присвячено багато робіт [5-7], [9-12], але ні одна із них не дозволяє розкрити взаємозв'язок економічної складової воєнної безпеки держави, тобто стану розвитку національної економіки, із необхідним рівнем воєнної безпеки. Усі ці роботи носять тільки описовий характер та не дозволяють сформувати практичні рекомендації щодо визначення показників забезпечення рівня воєнної безпеки держави ресурсними можливостями національної економіки.
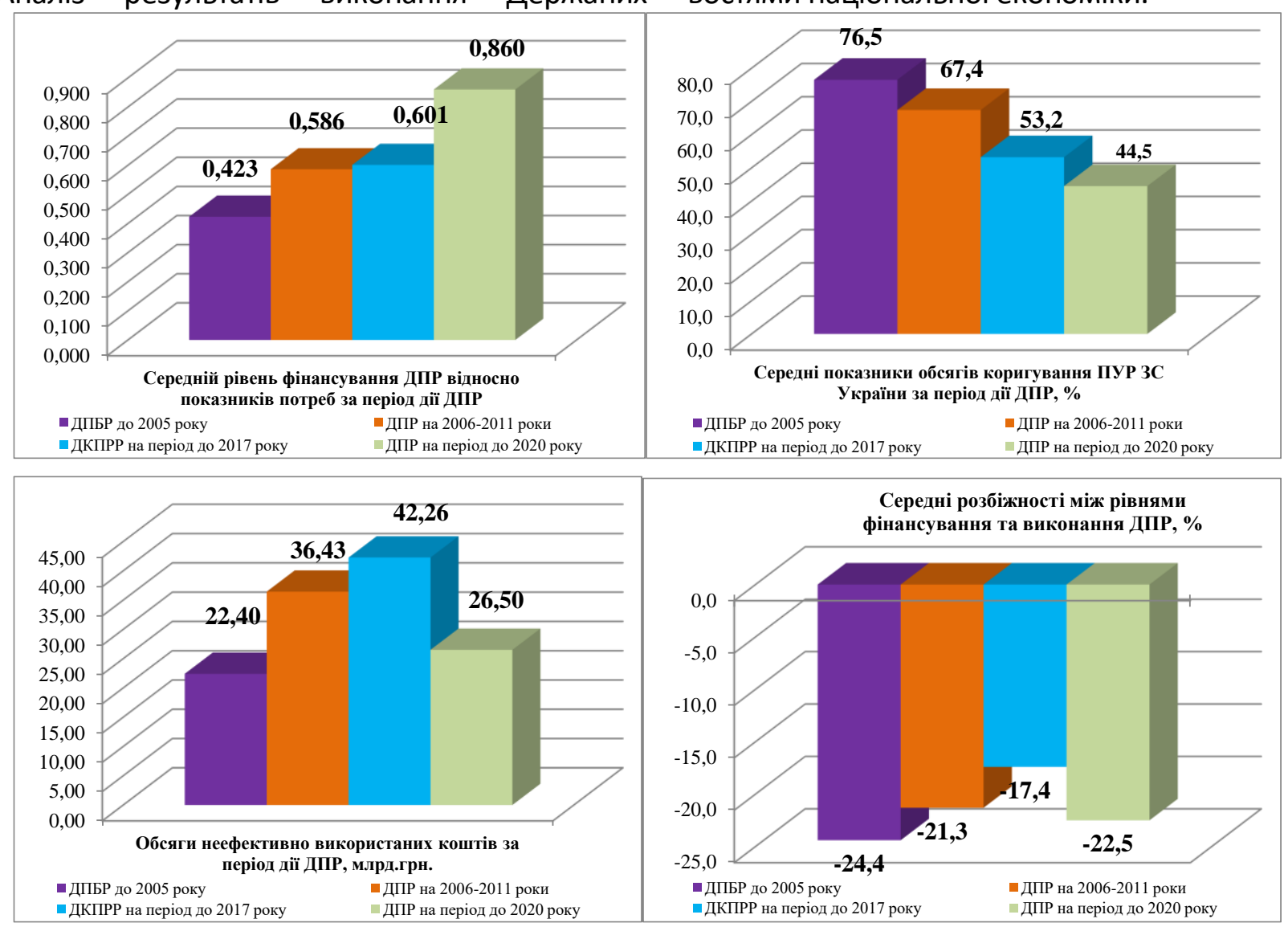

Малюнок 1 - Результати виконання Державних програм розвитку (ДПР) ЗС України за період 2000-2020 років (за показниками: середній рівень фінансування ДПР відносно показників потреб за період дії ДПР, середні обсяги неефективно використаних коштів, середні обсяги коригування Планів утримання та розвитку ЗС України за період дії ДПР, середні розбіжності між рівнями фінансування та виконання ДПР) 
Очевидно, що сформувати ці показники можна тільки на основі оцінювання стану економічної складової воєнної безпеки 3 урахуванням основних показників, які характеризують стан розвитку національної економіки держави, тобто в залежності від наявності різних видів ресурсів (людських, матеріальних, фінансових). Тому питання щодо розроблення методика оцінювання здатності національної економіки забезпечити достатній рівень воєнної безпеки держави $є$ одним із пріоритетних завдань щодо забезпечення воєнної безпеки держави під час обгрунтування перспективного обрису ЗС України.

\section{Аналіз останніх досліджень та публікацій}

Аналіз останніх досліджень і публікацій [115] щодо сучасного стану питання показує відсутність послідовного методичного підходу до визначення показників необхідного рівня воєнної безпеки держави та показників національної економіки щодо його ресурсної забезпеченості під час довгострокового та середньострокового оборонного планування, що створює ряд проблемних питань, до яких можна віднести: не врахування взаємозв'язку між показником рівня воєнної безпеки держави та прогнозованими показниками ресурсних можливостей національної економіки держави під час планування; відсутність методики оцінювання рівня економічної складової воєнної безпеки держави на основі оцінок стану (рівня) ії ресурсних можливостей; відсутність підходів до оцінювання рівнів забезпеченості ресурсами різних видів складових воєнної безпеки на основі оцінок їх складових та із орієнтуванням на оцінювання здатності оборонного сектору до виконання завдань за призначенням; відсутність методики оцінювання здатності національної економіки забезпечити достатній рівень воєнної безпеки держави; відсутність підходів до спроможності обґрунтованого (ефективного) коригування показника рівня економічної складової воєнної безпеки та показників його ресурсного забезпечення тощо.

\section{Постановка завдання}

В умовах розробки нових стратегічних планових документів подальшого розвитку та реформування 3 У України таких як Стратегічний оборонний бюлетень (СОБ), Концепція подальшого реформування i розвитку 3С України, Державна програма реформування та розвитку зС України (ДПР), питання щодо визначення майбутнього обрису ЗС України на довгострокову перспективу дуже активно досліджується [14] та $є$ достатньо актуальним сьогодні.

На сьогоднішній день $\epsilon$ багато суперечливих поглядів на можливості оцінювання взаємозв'язку показників рівня воєнної безпеки держави та показників національної економіки щодо його ресурсної забезпеченості, але чіткого послідовного підходу щодо вирішення даного завдання до теперішнього часу не має.

Тому мета статті полягає у розробленні методики оцінювання здатності національної економіки забезпечити достатній рівень воєнної безпеки держави.

\section{Виклад основного матеріалу}

Масштаби розвитку національної економіки держави та вимог до рівня ії воєнної безпеки визначаються кількісними і якісними характеристиками її збройних сил і продуктивних сил: людських ресурсів, виробничих потужностей, їх структури і територіального розміщення, інфраструк- тури, забезпеченості природними ресурсами (особливо основними видами сировини та палива), сільського господарства, транспорту і зв'язку, рівня розвитку науки і техніки, розмірів національного багатства, запасів золота та іноземної валюти, стратегічних резервів різних матеріальних засобів та ін. Ці 
елементи нерозривно пов'язані між собою, їх роль і значення у забезпеченні достатнього рівня воєнної безпеки та національної безпеки держави в цілому є вирішальною. Для того щоб досить обґрунтовано оцінити рівень воєнної або національної безпеки країни, необхідно комплексно досліджувати головні елементи національної економіки, в тому числі виявити максимальні ї̈ можливості для використання їх у військових цілях.

Оцінка якісних і кількісних аспектів ВЕБ та їх найважливіших елементів належить до переліку недостатньо відпрацьованих в теоретичному і практичному плані проблем. Вирішення цієї надзвичайно складної проблеми вимагає застосування цілого ряду критеріїв, вартісних і натуральних показників, статистичних та економіко-математичних методів, експертних оцінок тощо. Під час дослідження кожного елемента ВЕБ та національної безпеки країни виникає необхідність використовувати особливі критерії та показники.

Тому сьогодні на основі оцінювання відповідності стану (рівня) забезпеченості різними видами ресурсів від національної економіки держави необхідно сформувати методику оцінювання здатності національної економіки забезпечити достатній рівень воєнної безпеки держави на визначений час (період) з метою визначення основних цілей і напрямків ії становлення та розвитку на майбутнє, а, відповідно, й необхідних кількісних показників ресурсного забезпечення їі підтримання на визначеному рівні. Загальна схема методики оцінювання здатності національної економіки забезпечити достатній рівень воєнної безпеки держави наведена на мал. 2.

Методика являє собою послідовність дій, яка повинна дозволяти отримувати оцінки рівня економічної складової воєнної безпеки на визначений (плановий) час (період) ії формування на основі оцінок стану (рівня) забезпеченості різними видами ресурсів від національної економіки та їх складовими. Повна структурно-логічна схема Методики наведена на мал. 3
Вона складається із двох етапів: перший етап - це етап визначення необхідного рівня економічної складової воєнної безпеки держави та відповідних показників національної економіки щодо його ресурсної забезпеченості; другий етап - це етап оцінювання рівня економічної складової воєнної безпеки держави на основі оцінок їі ресурсної забезпеченості за показниками розвитку національної економіки.

На першому етапі залежно від результатів аналізу воєнно-політичної обстановки в державі та навколо неї, а також прогнозних показників ресурсних можливостей держави, визначається необхідний показник рівня воєнної безпеки держави та її економічної складової на плановий період його формування та необхідні показники рівнів забезпеченості різними видами ресурсів, а також оцінюються забезпеченість їх складових протягом планового періоду та на моменти оцінювання. Результати розрахунків на першому етапі $€$ вхідними даними для початку розрахунку на другому етапі запропонованого підходу, який являє собою оцінювання здатності національної економіки забезпечити достатній рівень воєнної безпеки держави на основі оцінок ресурсних можливостей національної економіки у визначені моменти оцінювання 3 метою обгрунтованого коригування планових показників.

Запропонована методика складається із п'яти блоків:

1-ий блок - блок вихідних даних та визначення математичної сутності побудови шкал оцінювання як показника стану економічної складової воєнної безпеки, так i рівнів забезпеченості ресурсами різних видів. В сучасних умовах оцінювання зазначених в методиці показників: відсутності повної інформації щодо практичних значень деяких 3 них; неможливості мати однорідну статистику для окремих; а деякі з них взагалі оцінюються за допомогою логічних висновків - це призводить до неоднозначності під час оцінювання та прийняття рішення. 


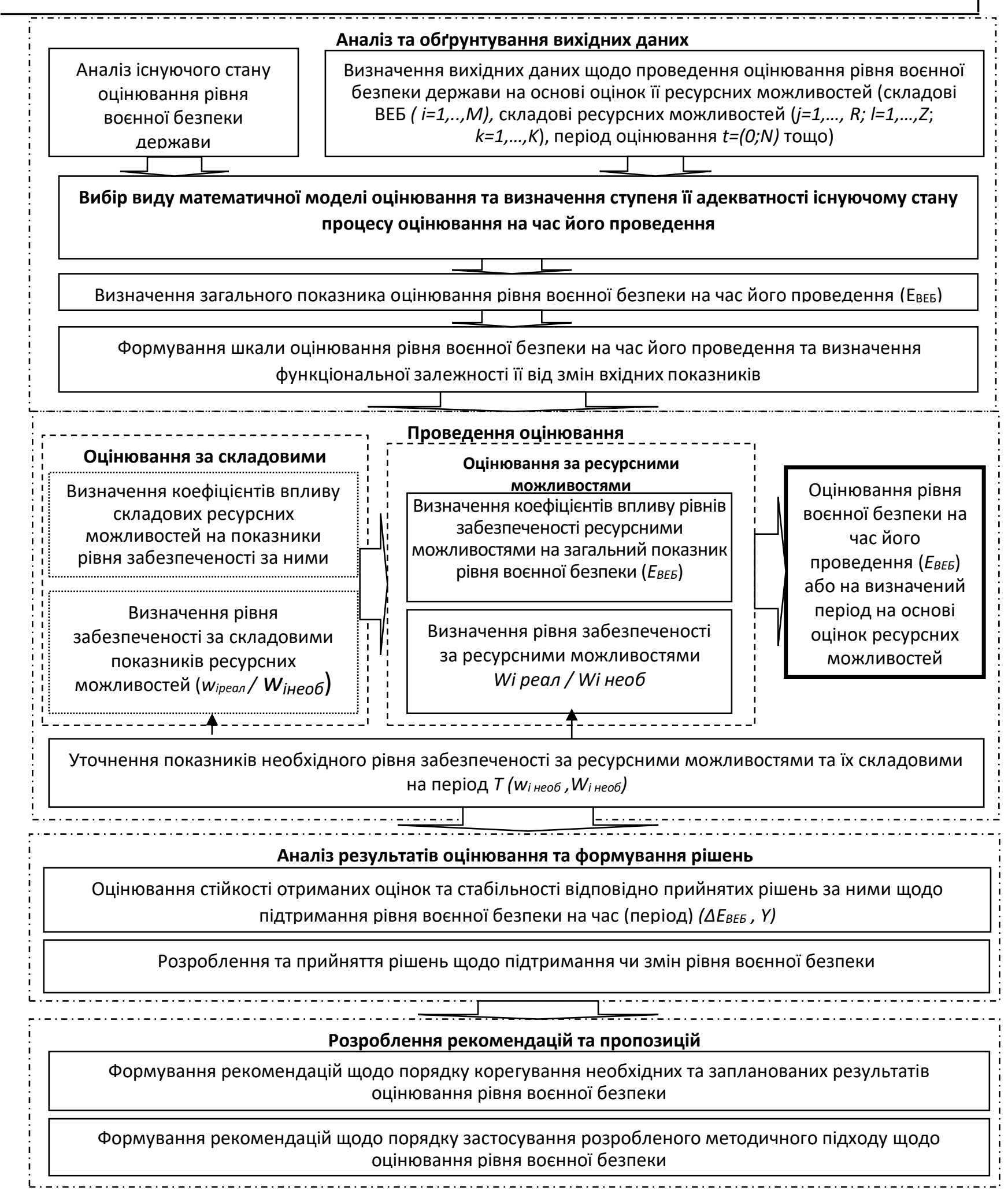

Малюнок 2 - Загальний порядок побудови методичного апарату оцінювання рівня воєнної безпеки держави на основі оцінок їі ресурсних можливостей

$\begin{array}{cccl}\text { Тому в основу шкал } & \text { оцінювання } & \text { давати однозначну відповідь щодочутливості } \\ \text { відповідних показників } & \text { пропонується } & \text { отриманих результатів оцінювання до змін } \\ \text { покласти нечітко-множинну } & \text { математичну } & \text { вхідних даних та стабільності прийнятих } \\ \text { модель, яка дозволить оперувати частковими } & \text { рішень на ̈іх основі. }\end{array}$
нечіткими показниками оцінок, а також 


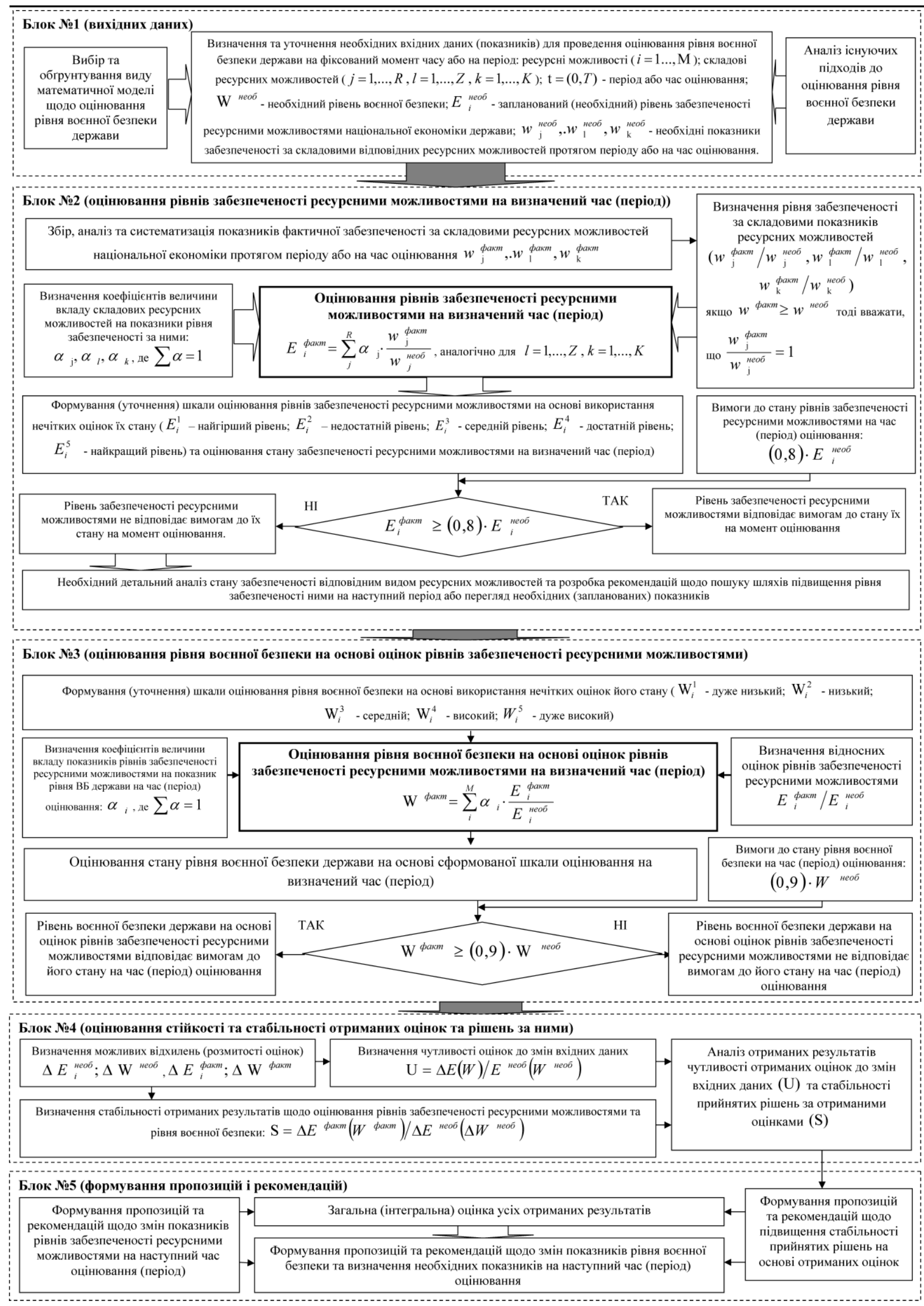

Малюнок 3 - Методика оцінювання здатності національної економіки забезпечити достатній рівень воєнної безпеки держави 
2-ий блок - являє собою блок оцінювання рівнів забезпеченості ресурсами різних видів на плановий момент (період) оцінювання. У цьому блоці проводиться збір, аналіз та систематизація показників національної економіки щодо фактичної забезпеченості за складовими ресурсів різних видів та визначається рівень забезпеченості за ними протягом планового періоду або за час періодичного оцінювання. Також у цьому блоці визначаються коефіцієнти величин вкладу складових різних видів ресурсів в загальний показник рівня забезпеченості за ними (мал. 2).

Аналогічний розрахунок проводиться і в третьому блоці під час визначення коефіцієнтів величини вкладу показників рівнів забезпеченості різними видами ресурсів національної економіки в показник рівня економічної складової воєнної безпеки держави на момент (період) оцінювання. Розрахунок коефіцієнтів величини вкладу пропонується проводити експертним методом. Після оцінювання показників національної економіки щодо рівня забезпеченості ресурсами різних видів за розрахованою експертним методом нечіткомножинною шкалою здійснюється порівняння із необхідним показником забезпеченості за період або вимогами до його стану на періодичні моменти оцінювання. Далі, у разі відхилень проводиться детальний аналіз отриманих результатів.

3-ій блок - блок оцінювання рівня воєнної безпеки на основі оцінок показників національної економіки щодо рівнів забезпеченості ресурсами різних видів на визначений період або момент оцінювання. Математично порядок отримання відповідної оцінки побудований за аналогічним підходом як і в блоці 2.

4-ий блок - це блок оцінювання стійкості та стабільності отриманих оцінок та прийнятих на основі них рішень до можливих змін вхідних параметрів оцінювання 3 метою з'ясування наскільки $€$ стабільним прийняте на основі результатів оцінювання управлінське рішення щодо подальшого розвитку складових воєнної безпеки. У цьому блоці, оскільки шкали оцінювання побудовані на основі нечітко-множинної математичної моделі, визначаються чутливість отриманих оцінок до можливих змін вхідних даних та стабільність прийнятих рішень на основі отриманих результатів оцінювання. Результати аналізу отриманих в цьому блоці оцінок є вхідними даними для проведення розрахунків у п'ятому блоці.

5-ий блок - являє собою блок формування пропозицій і рекомендацій щодо обґрунтованого, ефективного корегування показників необхідного рівня ресурсної забезпеченості воєнної безпеки держави за показниками достатності ресурсів національної економіки, або у разі неможливості ії змін протягом планового періоду, збільшення строків його формування чи зміни самого рівня воєнної безпеки на цей період.

За запропонованою методикою був проведений практичний розрахунок. Результати розрахунків наведені в таблицях 1, 2, 3, 4, 5. Оцінювання отриманих результатів проведено за визначеними нечітко-множинними шкалами оцінювання рівнів забезпеченості ресурсними можливостями та рівня воєнної безпеки держави. 
Таблиця 1 - Людські ресурси

\begin{tabular}{|c|c|c|c|c|c|c|}
\hline Людські ресурси & $\begin{array}{l}w_{j}^{\text {необх }} \\
\text { тис. чол. }\end{array}$ & $\begin{array}{l}w_{j}^{\text {paкm }} \\
\text { тис. чол. }\end{array}$ & $\begin{array}{l}\alpha_{j}= \\
\mathrm{w}_{\mathrm{j}} / \sum \mathrm{w}_{\mathrm{j}}\end{array}$ & $\frac{w_{j}^{\text {pakm }}}{w_{j}^{\text {eeoбx }}} \leq 1$ & $\alpha_{j} \cdot \frac{w_{j}^{\text {факт }}}{w_{j}^{\text {необx }}}$ & 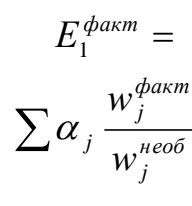 \\
\hline від 18 до 27 років & 100 & 115 & 0,34 & 1 & 0,34 & \multirow{3}{*}{0,83} \\
\hline від 27 до 45 років & 170 & 127 & 0,49 & 0,75 & 0,37 & \\
\hline від 45 до 60 років & 55 & 38 & 0,17 & 0,69 & 0,12 & \\
\hline
\end{tabular}

Таблиця 2 - Матеріальні ресурси

\begin{tabular}{|c|c|c|c|c|c|c|}
\hline Матеріальнী & $w_{l}^{\text {необ } x}$ & $w_{l}^{\text {paкm }}$ & $\alpha_{l}$ & $\frac{w_{l}^{\text {факm }}}{w_{l}^{\text {нeoбx }}} \leq 1$ & $\alpha_{l} \cdot \frac{w_{l}^{\text {факт }}}{w_{l}^{\text {необх }}}$ & $\begin{array}{c}E_{2}^{\text {dakm }}= \\
\sum \alpha_{l} \frac{w_{l}^{\text {pakm }}}{\mathrm{w}_{l}^{\text {необ }}}\end{array}$ \\
\hline Технічні & 1 & 0,81 & 0,46 & 0,81 & 0,370 & \multirow{5}{*}{0,671} \\
\hline Матеріальні & 1 & 0,47 & 0,21 & 0,77 & 0,099 & \\
\hline Продовольчі & 1 & 0,37 & 0,18 & 0,37 & 0,070 & \\
\hline Медичні & 1 & 0,87 & 0,11 & 0,87 & 0,096 & \\
\hline Інші & 1 & 0,89 & 0,04 & 0,89 & 0,036 & \\
\hline
\end{tabular}

Таблиця 3 - Фінансові ресурси

\begin{tabular}{|c|c|c|c|c|c|c|}
\hline Фінансові ресурси & $\begin{array}{c}w_{\kappa}^{\text {необх }}, \\
\text { млрд. грн. }\end{array}$ & $\begin{array}{c}w_{\kappa}^{\text {факт }}, \\
\text { млрд. грн. }\end{array}$ & $\alpha_{\kappa}$ & $\frac{w_{\kappa}^{\text {факm }}}{w_{\kappa}^{\text {необx }}}$ & $\alpha_{\kappa} \cdot \frac{w_{\kappa}^{\text {факт }}}{w_{\kappa}^{\text {деобx }}}$ & $\begin{array}{c}E_{3}^{\text {фaкm }}= \\
\sum \alpha_{k} \frac{w_{k}^{\text {pakm }}}{\mathrm{w}_{k}^{\text {необх }}}\end{array}$ \\
\hline $\begin{array}{l}\text { Запаси } \\
\text { національної } \\
\text { валюти }\end{array}$ & 13,5 & 15,5 & 0,31 & 1 & 0,31 & \multirow{4}{*}{0,575} \\
\hline Валютні запаси & 1 & 0,55 & 0,26 & 0,55 & 0,143 & \\
\hline $\begin{array}{l}\text { Запаси цінних } \\
\text { металів }\end{array}$ & 1 & 0,76 & 0,38 & 0,21 & 0,08 & \\
\hline $\begin{array}{l}\text { Запаси цінних } \\
\text { паперів }\end{array}$ & 1 & 0,83 & 0,05 & 0,83 & 0,042 & \\
\hline
\end{tabular}


Таблиця 4 - Стан (рівень) економічної складової воєнної безпеки

\begin{tabular}{|c|c|c|c|c|c|c|c|}
\hline & $\begin{array}{l}\Delta \mathrm{E}_{\mathrm{i}}, \\
\Delta W\end{array}$ & $U$ & $\begin{array}{l}\mu\left(E_{i}^{\text {факт }}\right) \\
\mu\left(\mathrm{W}^{\text {факт }}\right)\end{array}$ & $\begin{array}{c}\text { Аналіз } \\
\text { чутливості }\end{array}$ & $S$ & Оцінка & $\begin{array}{c}\text { Висновок } \\
\text { про } \\
\text { корегування }\end{array}$ \\
\hline$E_{1}^{\text {факm }}$ & 0,055 & $\begin{array}{c}0,775 / \\
0,885\end{array}$ & const / const & $\mathrm{HI}$ & стабільні & достатній & $\mathrm{HI}$ \\
\hline$E_{2}^{\text {факm }}$ & 0,1 & $\begin{array}{c}0,771 / \\
0,871\end{array}$ & var / var & TAK & нестабільні & $\begin{array}{l}\text { середній / } \\
\text { достатній }\end{array}$ & TAK \\
\hline$E_{3}^{\text {факm }}$ & 0,085 & $\begin{array}{c}0,49 / \\
0,66\end{array}$ & const / const & $\mathrm{HI}$ & стабільні & середній & $\mathrm{HI}$ \\
\hline $\mathrm{W}^{\hat{o} a \grave{e} e ̀ o}$ & 0,115 & $\begin{array}{c}0,582 / \\
0,812\end{array}$ & var / var & TAK & нестабільні & $\begin{array}{l}\text { середній / } \\
\text { достатній }\end{array}$ & TAK \\
\hline
\end{tabular}

Таблиця 5 - Оцінювання чутливості оцінок та стабільності

\begin{tabular}{|c|c|c|c|c|c|}
\hline $\mathrm{C}_{\text {Складові } W}^{\text {Показники }}$ & $\alpha_{\mathrm{i}}$ & $\mathrm{E}_{\mathrm{i}}^{\text {факт }}$ & $\mathrm{E}_{\mathrm{i}}^{\text {необ }}$ & $\alpha_{\mathrm{i}} \cdot \frac{\mathrm{E}_{\mathrm{i}}^{\text {факт }}}{\mathrm{E}_{\mathrm{i}}^{\text {необх }}}$ & $W^{\text {факт }}=\sum \alpha_{j} \frac{E_{i}^{\text {факт }}}{E_{i}^{\text {необх }}}$ \\
\hline Людські ресурси & 0,38 & 0,83 & 1 & 0,315 & \multirow{3}{*}{0,697} \\
\hline Матеріальні ресурси & 0,26 & 0,671 & 1 & 0,175 & \\
\hline Фінансові ресурси & 0,36 & 0,575 & 1 & 0,207 & \\
\hline
\end{tabular}

На цих шкалах визначаються розраховані відповідні показники рівнів забезпеченості ресурсами різних видів та розрахований загальний показник стану (рівня) економічної складової воєнної безпеки чи рівня воєнної безпеки держави в цілому на визначений момент оцінювання та дана їм оцінка. Відповідно до отриманих результатів проведено оцінювання чутливості оцінок до змін вхідних даних та стабільності прийнятих рішень на їх основі.

На основі результатів отриманих практичних розрахунків повинні бути сформовані практичні рекомендації та пропозиції, які будуть враховані на наступний плановий період формування показника необхідного рівня воєнної безпеки або рівня захищеності національних інтересів (рівня національної безпеки) взагалі. Розроблена методика передбачається для використання спеціалістами оборонного планування стратегічного рівня під час проведення середньострокового та довгострокового оборонного планування, а також спеціалістами економічної сфери, які залучаються до вирішення завдань визначення та прогнозування рівня воєнної та економічної безпеки держави. Особливо актуальним запропонований підхід $€$ сьогодні для спеціалістів Головного управління оборонного планування Генерального штабу зС України та Департаменту воєнної політики та стратегічного планування Міністерства оборони України в процесі трансформації системи оборонного планування до стандартів НАТО та впровадження в систему оборонного планування методу планування на основі спроможностей. За результатами використання методики: планується обґрунтовано визначати або уточнювати показники необхідного рівня ресурсного забезпечення воєнної безпеки держави на плановий момент (період) оцінювання під час середньострокового або довгострокового 
оборонного планування;

проводити оцінку рівнів забезпеченості ресурсними можливостями національної економіки на визначений момент оцінювання та період планування;

обґрунтовано, ефективно корегувати показники рівня воєнної безпеки держави та показники національної економіки щодо його ресурсної забезпеченості на визначений час (період);

визначати чутливість отриманих оцінок до можливих змін вхідних даних та характеризувати стабільність прийнятих рішень на основі отриманих оцінок з метою з'ясування стабільності прийнятих рішень та зменшення можливих ризиків.

\section{Висновки}

Запропонована у статті методика дозволяє ефективно вирішувати проблему дисбалансу між необхідним рівнем економічної складової воєнної безпеки держави та показниками національної економіки щодо ресурсних можливостей шляхом їх оцінювання та обґрунтованого корегування під час процесу середньострокового та довгострокового оборонного планування. У сучасних умовах розвитку та функціонування Збройних Сил України, які мають певні обмеження щодо достатності ресурсних можливостей національної економіки, а також обмеження викликані зовнішньою воєнно-політичною обстановкою навколо України, необхідні гнучкі підходи щодо формування очікуваних результатів захищеності національних інтересів України та забезпечення необхідного рівня воєнної безпеки, розроблена методика набуває певної актуальності, бо вона дозволить обґрунтовано визначати та корегувати як рівень економічної складової воєнної безпеки держави так i показники його ресурсної забезпеченості за показниками розвитку національної економіки.

\section{Список використаних джерел}

1. Воєнна доктрина України (в редакції 2004 р.): указ Президента України від 15 червня 2004 р. № 648/2004 // Офіційний вісник України. 2004. № 30.

2. Воєнна безпека і оборона України. Тлумачний словник нормативно-правових та наукових термінів і визначень. Під ред. Ф. В.Саганюк. Національний науководослідний центр оборонних технологій і воєнної безпеки України. К.: 2007.

3. Закон України № 2469-VIII: Про національну безпеку України. Верховна Рада України. Верховна Рада. URL: zakon.rada.gov.ua/.

4. Указ Президента України №392/2020. Про рішення Ради національної безпеки і оборони України від 14 вересня 2020 року «Про Стратегію національної безпеки України». URL: https://www.president.gov. ua/documents/3922020-35037.

5 Радвик Б. Военное планирование и анализ систем / Перевод с англ. В. Базарова / Под ред. А. М. Пархоменко Москва: Воениздат,
1972. 477 c.

6. Хомчак Р. Б., Семененко О. М., Бокій В. Г., Трегубенко С. С., Москаленко І. В. Аналіз та оцінка воєнно-економічних умов розвитку збройних сил країн світу та України. Зб. наук. пр. ЦНДІ ЗС України. Київ: 2019. № 5 (91). С. 91-109.

7. Харламова Г. Оцінка стабільності національної безпеки: нові рамки для аналізу. URL: http://ukraine2030.org/uk/ blog/view/175-Ocinka-stabilnosti-nacional noyi-bezpeki-novi-ramki-dlja-analizu

8. Бэтлер А. (2002) Национальные интересы, национальная и международная безопасность. ПОЛИС. № 4. С. 146-158.

9. Горбулін В.П. Стратегічне планування: вирішення проблем національної безпеки. Монографія / В.П. Горбулін, А.Б. Качинський. К. : НІСД, 2010. - 288 с..
10. Общая теория национальной безопасности: Учебник / Под ред. А.А. Прохожева. М.: РАГС, 2005. - 344 с..
11. Ткаченко В.І., Смірнов Є.Б., Астахов О.О. 
Шляхи формування системи забезпечення національної безпеки. URL: www.hups.mil. gov.uararticleszhups_2015_2_3

12. Шуляк П. І., Семененко О. М., Бокій В. Г., Совгіря Т. М., Пекуляк Р. О. Методичний підхід до оцінювання здатності Збройних Сил України до виконання покладених на них завдань з урахуванням ресурсних можливостей держави. 3б. наук. пр. ЦНДІ ЗС України. Київ. 2020. № 1 (92).

13. Україна. Офіційний сайт Державної служби статистики України: URL: www.ukrstat.gov.ua.

14. Україна. Офіційний сайт Міністерства фінансів України URL: www.minfin.com.ua.

15. Щорічник СИПРИ 2019: озброєння, роззброювання й міжнародна безпека. Москва. Наука, 2019.

16. Ткач І. М. Концептуальні засади воєнноекономічної безпеки держави : монографія. Київ : НУОУ ім. І. Черняховського, 2018. 312 с.

\title{
Методика оценки способности национальной экономики обеспечить достаточный уровень военной безопасности государства
}

\author{
Олег Семененко * А; Игорь Москаленко ${ }^{\mathrm{B}}$; Сергей Середюк ${ }^{\mathrm{A}}$; \\ Ольга Романченко '; Иван Мотрунич ${ }^{\text {; }}$ Виктория Коверга ${ }^{A}$ \\ *Corresponding author: д. войск. н., с.н.с., начальник отдела, e-mail: aosemenenko@ukr.net, ORCID: 0000-0001-6477-3414 \\ А Центральный научно-исследовательский институт Вооруженных Сил Украины, пр-кт Воздухофлотский 28 г. Киев, 03049, Украина

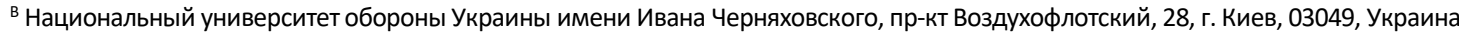 \\ СЦентр обеспечения служебной деятельности Министерства обороны и Генерального штаба Вооруженных Сил Украины, \\ пр-кт Воздухофлотский 6, г. Киев, 03168, Украина
}

\begin{abstract}
Аннотация
Сегодня есть много противоречивых взглядов об оценке показателей уровня военной безопасности государства и показателей его ресурсной обеспеченности, характеризующих состояние развития национальной экономики государства, но четкого последовательного подхода к решению такой задачи до настоящего времени нет. Поэтому предложенная авторами в статье методика представляет собой последовательность действий, которая должна позволять проводить оценку уровня военной безопасности государства на определенный момент времени или период на основе формирования оценок состояния или уровня обеспеченности различными видами ресурсов их составляющих, которые характеризуют развитие национальной экономики государства. На основе результатов полученных практических расчетов формируются практические рекомендации и предложения, которые будут учтены во время выбора и обоснования показателя необходимого уровня военной безопасности государства на следующий плановый период с учетом оценок способности национальной экономики обеспечить этот уровень. Методика предполагается для использования специалистами оборонного планирования стратегического уровня во время проведения среднесрочного и долгосрочного оборонного планирования, а также специалистами экономической сферы, привлекаемых к решению задач определения и прогнозирования уровня военной и экономической безопасности государства.

По результатам использования методики планируется обоснованно определять или уточнять показатели необходимого уровня развития национальной экономики государства по вопросам ресурсного обеспечения военной безопасности государства на плановый момент (период) оценки во время среднесрочного и долгосрочного оборонного планирования; проводить оценку уровней обеспеченности ресурсными возможностями национальной экономики на определенный момент оценки и период планирования; обоснованно, эффективно корректировать показатели уровня военной безопасности государства и ресурсной обеспеченности по составляющим национальной экономики на
\end{abstract}


определенное время (период); определять чувствительность полученных оценок к возможным изменениям входных данных и характеризовать стабильность принятых решений на основе полученных оценок.

Ключевые слова: военная безопасность, экономическая составляющая, национальная экономика, ресурсные возможности, методика оценки, показатели обеспечения, плановый период, виды ресурсов, обобщенная схема.

\title{
Methods of assessing the ability of the national economy to ensure a sufficient level of state military security
}

\author{
Oleg Semenenko *A; Ihor Moskalenko ${ }^{B}$; Serhiy Seredyuk ${ }^{C}$; \\ Olha Romanchenko ${ }^{B}$; Ivan Motrunych ${ }^{C}$; Viktoriia Koverga ${ }^{A}$ \\ *Corresponding author: Dr of military sciences, Senior Research Fellow, Head of Department, e-mail: aosemenenko@ukr.net, ORCID: 0000-0001-6477-3414 \\ ${ }^{A}$ Central Research Institute of Armaments and Military Equipment Armed Forces of Ukraine, 28, Povitroflotsky, ave, Kyiv, 03049, Ukraine \\ ${ }^{B}$ National Defense University of Ukraine named after Ivan Chernyakhovskyi, 28, Povitroflotsky, ave, Kyiv, 03049, Ukraine \\ ' Service Support Center of the Ministry of Defense and the General Staff of the Armed Forces of Ukraine, \\ 6, Povitroflotsky ave., Kyiv, 03168, Ukraine
}

\begin{abstract}
Today there are many contradictory views on the possibility of assessing the relationship between indicators of the level of military security of the state and indicators of its resource security, which characterize the state of the national economy, but there is no clear consistent approach to this task. Therefore, the method proposed by the authors in the article is a sequence of actions that should allow assessing the level of military security of the state for a certain planned time or period of its formation based on assessments of the state or level of security of various resources and their components. Based on the results of the received practical calculations, practical recommendations and proposals are formed, which will be taken into account for the next planning period of formation of the required level of military security of the state, taking into account assessments of the national economy's ability to provide this level. The methodology is intended for use by specialists of defense planning at the strategic level during medium-term and long-term defense planning, as well as specialists in the economic sphere, who are involved in determining and forecasting the level of military and economic security of the state.

Based on the results of using the methodology, it is planned to reasonably determine or clarify the indicators of the required level of development of the national economy in the direction of resource provision of military security of the state at the planned time (period) of assessment during medium and long-term defense planning; to assess the levels of resource capacity of the national economy at a given time of assessment and planning period; reasonably, effectively adjust the indicators of the level of military security of the state and resource security for the components of the national economy for a certain period of time (period); determine the sensitivity of the obtained estimates to possible changes in the input data and characterize the stability of decisions based on the obtained estimates.
\end{abstract}

Keywords: military security, economic component, national economy, resource possibilities, estimation technique, maintenance indicators, planning period, types of resources, generalized scheme.

\section{References}

1. Military Doctrine of Ukraine (as amended in 2004): Decree of the President of Ukraine of June 15, 2004 № 648/2004 // Official Gazette of Ukraine. 2004. № 30.
2. Military security and defense of Ukraine. Explanatory dictionary of normative-legal and scientific terms and definitions. Ed. F.V. Saganyuk. National Research Center for 
Defense Technologies and Military Security of Ukraine. Kyiv: 2007.

3. Law of Ukraine № 2469-VIII: On National Security of Ukraine. Verkhovna Rada of Ukraine. Verkhovna Rada. URL: zakon.rada.gov.ua/.

4. Decree of the President of Ukraine №392 / 2020. On the decision of the National Security and Defense Council of Ukraine of September 14, 2020 "On the National Security Strategy of Ukraine". URL: https://www.president.gov.ua/documents/3 922020-35037.

5. Radvik B. Military planning and systems analysis / Translated from English. V. Bazarova / Ed. A.M. Parkhomenko. Moscow: Voenizdat, 1972. 477 p.

6. Khomchak R.B., Semenenko O.M., Bokiy V.G., Tregubenko S.S., Moskalenko I.V. Analysis and assessment of military and economic conditions for the development of the armed forces of the world and Ukraine // Collection of scientific works of the Central Research Institute of the Armed Forces of Ukraine. Kyiv: 2019. № 5 (91). pp. 91-109.

7. Kharlamova G. Assessing the stability of national security: a new framework for analysis. URL: http://ukraine2030.org/en/ blog/view/175-Ocinka-stabilnosti-nacional noyi-bezpeki-novi-ramki-dlja-analizu

8. Butler A. (2002) National interests, national and international security. POLICE. № 4. P.
146-158.

9. Gorbulin V. P. Strategic planning: solving national security problems. Monograph / V.P. Gorbulin, A.B. Kaczynski. Kyiv: НІСД, 2010. $288 \mathrm{c}$.

10. General theory of national security: Textbook / Ed. A.A. Прохожева. Moscow: RAGS, 2005. $344 \mathrm{~s}$.

11. Tkachenko V.I., Smirnov E.B., Astakhov O.O. Ways of forming a system of national security. URL: www.hups.mil.gov.ua sarticles zhups_2015_2_3

12. Shulyak P.I., Semenenko O.M., Bokiy V.G., Sovgirya T.M., Pekulyak R.O. Methodical approach to assessing the ability of the Armed Forces of Ukraine to perform the tasks assigned to them, taking into account the resource capabilities of the state // Collection of scientific works of the Central Research Institute of the Armed Forces of Ukraine. Kyiv. 2020. № 1 (92).

13. Ukraine. Official site of the State Statistics Service of Ukraine: URL: www.ukrstat.gov.ua.

14. Ukraine. Official site of the Ministry of Finance of Ukraine URL: www.minfin.com.ua.

15. SIPRA Yearbook 2019: armaments, disarmament and international security. Moscow. Science, 2019.

16. Tkach I.M. Conceptual principles of military and economic security of the state: monograph. Kyiv, 2018. 312 p. 